\title{
Major Role of Locally Made Charcoal Business in Promoting Entrepreneurial Status in Nigeria
}

\author{
Yohanna A. Timothy \\ University of Maiduguri,Department of Business Management \\ PMB 1069, Maiduguri, Borno State, Nigeria
}

\section{Doi:10.5901/mjss.2013.v4n16p137}

\begin{abstract}
The aim of this study was to investigate the role of charcoal business in promoting entrepreneurial industries in Nigeria. A total of three hundred (300) questionnaires were distributed in three (3) states of northern Nigeria (Adamawa, Borno and Gombe State) major charcoal dealers, Charcoal Suppliers, Charcoal Distributors and Customers were each chosen from the sample state. It was discovered that $88 \%$ of respondents deal with Local made Charcoal. It also showed that $92 \%$ of the responses strongly agreed that Charcoal Business is lucrative; therefore These findings suggested that Charcoal may not be major factors in promoting entrepreneur, but it was the fastest in creating jobs and promotion of trade in such a way that its exports is multi-Billion Dollar industries. It is recommended that, Government have to give maximum attention to charcoal business as key remedy of Job creation in Nigeria.
\end{abstract}

Keyword: Role, Charcoal Business and Entrepreneurial,

\section{Introduction}

Charcoal as a formless mass of carbon can be made from most carbonaceous materials. It is one of the oldest of man-made fuels and has been prepared under the ground for a thousand years. Charcoal in lump form is still a major source of energy throughout the world. Most charcoal manufacturers sell their product as a briquette. This market has been dominated by several companies to include Kingsford, Royal Oak and major grocery market brands. They do not make "lump" charcoal which is an alternate product that has some advantages and has potential as a small start-up business. An entrepreneur hoping to survive in the charcoal industry will require originality and very good and aggressive marketing. Many small companies have survived but most have not made it "big". They've found their potential in the niche charcoal market is by making natural hardwood "lump" charcoal. Innovative ideas like developing a product in a bag that has a fuse, which when lit will ignite the charcoal. This quick light product combined with a easy to use paraffin coated container filled with natural charcoal has been a modest success in some local markets. Steve Nix (1997)

The cry for alternative energy source has put CHARCOAL in the forefront in the global market. A large market exists in EU, USA and ASIA with prices ranging from $£ 170$ to $£ 190$ per ton (FOB Nigerian Port), depending on mode of packaging. The charcoal industry is a multi-billion dollar industry and a money spinner for interested investors. The United Kingdom alone consumes more than 60,000 metric tons of charcoal annually, out of which about $70 \%$ comes from tropical Africa. Other countries around the world equally consume charcoal in great quantity. For a diligent entrepreneur, there is a big incentive that comes in form of export expansion grant, which the government normally gives to big time exporters. A company known as B. $\mathrm{J}$ Export which is into this business of processed charcoal export benefited from the Export Expansion Grant to the tune of N16,762,222.99 in April 2003. Ismail AbdulAzeez (2002) 


\section{Empirical Literature}

A recent report on the exportation of charcoal suggests that the existing ban placed on it does not seem to have more effect, with devastating consequences on the environment. Although there was no reliable figure on the extent of charcoal to Europe, United State and the middle east, there is evidence to suggest that it is growing as an export business, According to website devoted to promoting the trade, charcoal export business is multi-billion dollar industry and money spinner, with the united state alone, importing more that 60,000 metric tons of charcoal annually with $70 \%$ of it from Africa.

For Nigeria to tackle the problem of the widespread local use of charcoal, there is need for community be involved to accept the idea to be provided with alternative to charcoal for Nigerians compelled by circumstances to use it as more affordable source of energy, particularly for domestic use, it is obvious that public enlightenment of the dangers of deforestation caused by felling of trees for charcoal and firewood alone, will not work until an affordable alternative is available to the people. With the will do so, it is possible for Nigerian to tap into its rich deposit of hydrocarbons and the gas that gets flared everyday to provide the alternative to charcoal, whose use is depleting Nigeria forests at an alarming rate and leaving the country open to all the consequential environmental challenges, to avoid the effects od declining agricultural productivity, (Daily Trust Editorial)

Environmentalists have raised the alarm over massive logging of indigenous trees by salt manufacturers at the Coast. Nature Kenya, said in a press release that forests are rapidly disappearing as a result of charcoal and firewood for salt manufacturing factories at the Coast despite a ban on firewood collection by the National Environment Management Authority and Kenya Forest Service in January. Kibiwott Koross, (2012)

John P. Cunha (2012) opined about usage of Activated Charcoal, It was tested in 1831. In front of his distinguished colleagues at the French Academy of Medicine, Professor Touery drank a lethal dose of strychnine and lived to tell the tale. He had combined the deadly poison with activated charcoal. That's how powerful activated charcoal is as an emergency decontaminant in the gastrointestinal (GI) tract, which includes the stomach and intestines. Activated charcoal is considered to be the most effective single agent available. It is used after a person swallows or absorbs almost any toxic drug or chemical.

Alex Abutu (2011) said, Nigeria has lost over N1 billion to illegal export of charcoal and logs from states in the South West and North Central to the Middle East and Europe in the last four years. An investigation by Daily Trust Newspaper revealed that charcoal and wood export were the major factors responsible for the massive deforestation in the country. The illegal export is booming despite the existence of federal laws that prohibits the export of logs from Nigeria. Due to the unabated nature of the business, the National Council on Environment which held in September in Kaduna took the decision to place an outright ban on charcoal export but that decision had not impacted on the trade which is responsible for indiscriminate felling of trees.

Karen Msiska (2012) knows that sustaining the forest would bring back the reliable rainfall. But she chooses to stun you."As long as the charcoal alleviates our poverty and gives us something with which to buy food, the forest can go," she says."It's all because of poverty. We want to have food but we don't have money to buy the food or fertilizer to boost our food yields. We get something from the charcoal from the forest. We buy food and top up what we get under the farm income subsidy programme. What we get is little and this season was worse." Every day, bicycles loaded with charcoal zigzag their way out of Dzalanyama forest to Mitundu where it is traded to middlemen. These middlemen take it into the centre of Lilongwe where they sell it to a final consumer.

Daily Trust (2011) surveyed that, The price of charcoal, a cooking energy source, has risen by 100 per cent in Niger State, following the hike in the price of kerosene. A survey by the News Agency of Nigeria (NAN) in Minna and its environs showed that the bag of charcoal that was sold for N500 in March has now risen to $\mathrm{N} 1,000$ in the market. The survey revealed that housewives and caterers have shifted from kerosene to charcoal as their source of fuel for cooking. A small packet of charcoal that enjoys high patronage from the 
public is now sold for N100 as against the former price N50.

Punch (2004) observed that, A total sum of N9.889 billion in form of Negotiable credit certificate (NDCCS) was disbursed to 115 exporters from January to September (The Punch, Thursday, April 8, 2004. page 22) The business of charcoal export is lucrative and this is the reason why many more people should go to charcoal export. Getting capital for the business is easy. All that a prospective entrepreneur needs to do is to source for the orders. Most financial institutions are willing to participate in the business once a valid order is presented. There are also many venture capitalists and individuals with large reserves of fund who will be willing to do the business with you and share your profit at a given ratio.

Wikipedia, (2012) historically, production of wood charcoal in districts where there is an abundance of wood dates back to a very ancient period. Commercial charcoal is found in either lump, briquette, or extruded forms:

Lump charcoal is made directly from hardwood material and usually produces far less ash than briquettes.

Briquettes are made by compressing charcoal, typically made from sawdust and other wood byproducts, with a binder and other additives. The binder is usually starch. Some briquettes may also include brown coal (heat source), mineral carbon (heat source), borax, sodium nitrate (ignition aid), limestone (ashwhitening agent), raw sawdust (ignition aid), and other additives.

Extruded charcoal is made by extruding either raw ground wood or carbonized wood into logs without the use of a binder. The heat and pressure of the extruding process hold the charcoal together. If the extrusion is made from raw wood material, the extruded logs are then subsequently carbonized.

Japanese charcoal removes pyroligneous acid during the charcoal making. Therefore when burning, there are almost no stimulating smells or smoke. The charcoal of Japan is classified into three kinds.

\section{Materials and Method}

This study adopted survey research design in Adamawa, Borno and Gombe State to investigate the specific role played by charcoal Business in promoting entrepreneurial status in Nigeria, three states was selected as the study site in the year 2012. It was stratified into four categories of Charcoal Business centers and selling market points, Stratified Random Sampling technique was employed to selected dealers, Suppliers, Distributors, sellers and customers of Charcoals. 100 copies of the structured questionnaire carrying several questions were administered to the respondents and participant in each state of the study site. Charcoal Dealers in the three State answered (125) Suppliers answered (42) Customers answered (120) and then Charcoal Marketers responded to (13) altogether summed to 300 administered questionnaires with each state getting (100)

The study took One (1) year Four (4) Months to capture these data, so that to include both period of dry season and rainy season, these period was to ensure enough time for fluctuating nature of the product in scarcity and abundance. The data for the period covered were merged, questionnaires retrieved were categorized and recorded according to Age, Qualification, cost per bag, Retailers Price, purchasing and selling price, year of experience, reason for being in the business, profitability and the driving force behind the Business. The Data of study were analyzed using descriptive statistics.

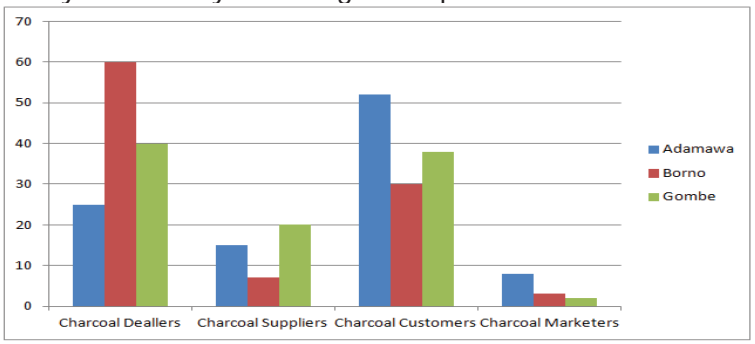




\section{Result and Discussion}

Table 1: Demographic Responses

\begin{tabular}{lll} 
Sex of Respondents & Frequency & Percentage \\
\hline Female & 122 & $41 \%$ \\
Male & 178 & $59 \%$ \\
Educational Qualification & & \\
\hline Primary/ SSCE & 147 & $49 \%$ \\
Diploma/HND & 124 & $41 \%$ \\
First Degree (Bsc) & 21 & $7 \%$ \\
Masters & 8 & $3 \%$ \\
Age Status & & \\
\hline 10 - 25 years & 92 & $31 \%$ \\
26- 50 years & 178 & $59 \%$ \\
51-61 Years & 30 & $10 \%$ \\
State \& Business Location & & \\
\hline Adamawa & 100 & $33 \%$ \\
Bomo & 100 & $33 \%$ \\
Gombe & 100 & $33 \%$ \\
\hline
\end{tabular}

Source: 2012 Authors Field Survey

Table (1) shows the demographics responses of charcoal dealers, suppliers, customers, and Business experts and entrepreneurial in Adamawa, Borno and Gombe State, The majority were males with 59\% but female were $41 \%$. They only attend a limit of Primary and Secondary school Certificates, some had national Diploma and Higher National Diploma respectively, they ages between 26 - 50 Years, other categories were between $10-25$ years.

Table 2: Responses of Charcoal Dealers

\begin{tabular}{lll} 
Kind of Charcoal & Frequency & Percentage \\
\hline Local Wood Charcoal & 263 & $88 \%$ \\
Imported Wood Charcoal & 16 & $5 \%$ \\
Activated Wood Charcoal & 3 & $1 \%$ \\
Others Charcoals & 18 & $6 \%$ \\
Source of Charcoal & & \\
\hline Southern Nigeria & 114 & $38 \%$ \\
Northern Nigeria & 148 & $49 \%$ \\
Zandar, Niger & 14 & $5 \%$ \\
Koza, Cameroon & 24 & $8 \%$ \\
Quantity of Bags distributed weekly & & \\
\hline $1-$ & 164 & $55 \%$ \\
$300-500$ Bags & 108 & $36 \%$ \\
$600-1000$ Bags & 19 & $6 \%$ \\
1000 \& Above & 9 & $3 \%$ \\
Current Price Sold per Bag & & \\
\hline N1,500 per Bag & 42 & $14 \%$ \\
N1,400 per Bag & 69 & $23 \%$ \\
N1,300 per Bag & 85 & $28 \%$ \\
N1,200 per Bag & 98 & $33 \%$ \\
N1,000 per Bag & 6 & $2 \%$ \\
Charcoal Business as Promoter of diligent entrepreneur & \\
\hline Yes, I strongly Believe & 281 & $94 \%$ \\
No, I don't believe & 19 & $6 \%$ \\
Extent of lucrative nature of Charcoal Business & \\
\hline Higher Lucrative & 164 & $55 \%$ \\
Average Lucrative & 127 & $42 \%$ \\
Low Lucrative & 6 & $2 \%$ \\
Not Lucrative & 3 & \\
\hline & & \\
\hline
\end{tabular}

Source: 2012 Authors Field Survey 
Table 2 Discuses the responses of charcoal dealers, 58\% served in dealership of local wood charcoal business, very few among the dealers patronized imported, articulated and other charcoals. They mainly sourced the charcoal from Northern and southern Nigeria, some of them imported the product from Niger and Cameroon republic. However, the quality sold per week was between (1-200) bags and (300-500) bags respectively; it was only in rare cases that special dealers sold above $(600-1,000)$ bags weekly. The current price of the charcoal is not stable depending on time and source of the products, but it varies from (N1,000 N1500) due to many constraints and factors. These dealers in Adamawa, Borno and Gombe State have strongly believed that, charcoal business has promoted diligent entrepreneurial as shown by responses of $94 \%$ to an extent that $55 \%$ opined that the business was highly lucrative, another group of dealers with $42 \%$ agreed that the business is really an aggregate as lucrative, Only less than $1 \%$ that disbelief the majority. This confirmed that the business is highly lucreative.

Table 3: Responses of Charcoal Supplier

\begin{tabular}{|c|c|c|}
\hline Years in supplying charcoal & Frequency & Percentage \\
\hline Less than One Year & 32 & $11 \%$ \\
\hline One - Two Years & 66 & $22 \%$ \\
\hline Three - Five Years & 103 & $34 \%$ \\
\hline Five years \& Above & 99 & $33 \%$ \\
\hline \multicolumn{3}{|l|}{ Packages of the Charcoal for Supply } \\
\hline Bulk Packaging & 17 & $6 \%$ \\
\hline Bag Packaging & 218 & $73 \%$ \\
\hline Carton Packaging & 3 & $1 \%$ \\
\hline Leather Packaging & 62 & $20 \%$ \\
\hline \multicolumn{3}{|l|}{ Buyers of Charcoal } \\
\hline House hold & 152 & $51 \%$ \\
\hline Business Entity & 140 & $47 \%$ \\
\hline Other & 8 & $2 \%$ \\
\hline \multicolumn{3}{|l|}{ Profit margin of Supplying Charcoal } \\
\hline $100 \%$ Margin & 101 & $34 \%$ \\
\hline $50 \%$ Margin & 111 & $37 \%$ \\
\hline $20 \%$ Margin & 69 & $23 \%$ \\
\hline $10 \%$ margin & 19 & $6 \%$ \\
\hline \multicolumn{3}{|c|}{ Business Opportunity in Charcoal Business } \\
\hline Create Opportunity to Unemployed youth & 78 & $26 \%$ \\
\hline Create Opportunity to Women & 82 & $27 \%$ \\
\hline Reduces Poverty Level in rural Area & 62 & $21 \%$ \\
\hline Promote Small Scale enterprises & 78 & $26 \%$ \\
\hline \multicolumn{3}{|c|}{ Challenges on transporting, delivery and distribution of Charcoal } \\
\hline Serious Challenges & 191 & $64 \%$ \\
\hline Average Challenge & 82 & $27 \%$ \\
\hline No Challenges & 27 & $9 \%$ \\
\hline \multicolumn{3}{|c|}{ Solution to Challenges of transporting, delivery and distribution of Charcoa } \\
\hline Government Intervention & 166 & $55 \%$ \\
\hline Repairing of Roads & 95 & $32 \%$ \\
\hline Intervention of Community Leaders & 39 & $13 \%$ \\
\hline
\end{tabular}

\section{Source: 2012 Authors Field Survey}

Table 3 Shows the responses of Charcoal Suppliers and buyers respectively, majority of the suppliers had experienced of (3-4) years. While others had 5 and above years; some have even minimum years of experience between (1-2) years, most of the suppliers packages the charcoal in bags as indicated in the table with $73 \%$. Some re-package in leathers for re-sales. And the buyers of the product were household with $51 \%$ and business entities such as restaurant, etc. with $47 \%$. These set of suppliers gained a profit margin of $(20-100 \%)$ respectively. And they solely believed that charcoal business has created a lot of business opportunity such as promotion of small and medium scale enterprises, reduction of poverty, women and 
youth empowerment, and creation of job to un-employed youths. In another contrast, the suppliers complained of serious challenges on transporting, delivery and distributions of charcoal, and they suggested that, the only solutions to the problem is for government to intervene at all level by repairing of roads and low tax and friendly approach to policies, so that community leaders will play their role in educating the local charcoal dealers.

Table 4: Responses of Charcoal Consumers

\begin{tabular}{|c|c|c|}
\hline Type of cooking Energy used & Frequency & Percentage \\
\hline Fire Wood & 28 & $9 \%$ \\
\hline Kerosene & 44 & $15 \%$ \\
\hline Gas & 18 & $6 \%$ \\
\hline Charcoal & 202 & $67 \%$ \\
\hline Others & 8 & $3 \%$ \\
\hline \multicolumn{3}{|c|}{ Years of patronage of Charcoal as customers } \\
\hline Less than 1 year & 31 & $10 \%$ \\
\hline $1-2$ years & 59 & $20 \%$ \\
\hline $3-4$ Years & 99 & $33 \%$ \\
\hline $5-6$ Years & 84 & $28 \%$ \\
\hline 7 years \& Above & 27 & $9 \%$ \\
\hline \multicolumn{3}{|l|}{ Often Time of purchasing Charcoal } \\
\hline Daily & 61 & $20 \%$ \\
\hline Weekly & 107 & $36 \%$ \\
\hline Monthly & 116 & $39 \%$ \\
\hline Quarterly & 16 & $5 \%$ \\
\hline \multicolumn{3}{|l|}{ Current Price Per Bag } \\
\hline Bellow - N1000 & 13 & $4 \%$ \\
\hline $\mathrm{N} 1100-\mathrm{N} 1300$ & 194 & $65 \%$ \\
\hline N1400 \& Above & 93 & $31 \%$ \\
\hline \multicolumn{3}{|c|}{ Compares of Charcoal price with other means of cooking Energy } \\
\hline Strongly agreed that Charcoal is cheaper & 264 & $88 \%$ \\
\hline No, Don't think Charcoal is cheaper & 36 & $12 \%$ \\
\hline \multicolumn{3}{|c|}{ Advantage of Charcoal over Kerosene, Gas and Fire wood } \\
\hline Cheap & 98 & $33 \%$ \\
\hline Availability & 71 & $23 \%$ \\
\hline Smokeless & 53 & $18 \%$ \\
\hline Efficiency & 41 & $14 \%$ \\
\hline Convenience & 37 & $12 \%$ \\
\hline
\end{tabular}

Source: 2012 Authors Field Survey

Table 4 Analysis the satisfactions of customers, compare to other means of cooking energy, majority of the customers with $67 \%$ used charcoal as means of cooking energy, very few uses firewood, kerosene, gas and others. These consumers were patronizing the charcoal at an average of (1-6) years. They often purchased the charcoal on daily - weekly basis. While $39 \%$ as the majority of buyers were civil servants whose buys the products at the end of every month. The product was mostly bought on price of (N1100 - N1300) depending on season. And then some time the price shoot to N1400 and above depending on occasions. However, the result vividly shows that customers have derived high satisfactions from the products compares to other means of cooking energy as indicated with $88 \%$, they strongly believed that charcoal is cheaper, they stated that the advantage of charcoal over kerosene, Gas and firewood was cheapness, Availability, smokiness, efficiency and convenience. 
Table 5: Responses of Business Experts \& Entrepreneurs

Charcoal Business in Promoting Entrepreneur in Nigeria

\begin{tabular}{lcc}
\hline Very effective & 222 & $74 \%$ \\
Not effective & 78 & $26 \%$ \\
Specific Role of Charcoal Business & & \\
\hline Job Creations & 177 & $59 \%$ \\
Poverty Reduction & 53 & $18 \%$ \\
Development of Rural Economy & 50 & $16 \%$ \\
Other Roles & 20 & $7 \%$ \\
Possible ways forward of improving a charcoal Business & \\
\hline Intervention of Govermment & 70 & $23 \%$ \\
Provision of Loan by Commercial Banks & 79 & $26 \%$ \\
Modification of the Charcoal Business & 105 & $35 \%$ \\
Engagement of Experts to educatemore & 46 & $15 \%$ \\
Ways for government, Banks and Nongovernment organization to help in promotion of charcoal \\
Business & & \\
\hline Raise more Loan for them & 153 & $51 \%$ \\
Support them as entrepreneur & 108 & $36 \%$ \\
Engage Foreign investors & 54 & $18 \%$ \\
\hline
\end{tabular}

Source: 2012 Authors Field Survey

Table 5 Discuses the opinion of experts and entrepreneurial in relation to charcoal business $74 \%$ strongly agreed that, charcoal business is very effective in promoting entrepreneurial status in Nigeria. And they added that some of the special role played by the business were, job creation, poverty reductions and development of rural economy. It was further suggested that, possible ways forward of improving the charcoal business can be done by intervention of government, provision of loan by commercial banks, modification of charcoal business and engagement of experts to educate more on the analysis of the venture, however, these experts suggested a way forwards for government, Banks and non-governmental organizations to help in promotion of charcoal Business through raising more loans (51\%) support them as entrepreneurial and (36\%) opined of engaging foreign investors to help the business.

\section{Conclusion}

From the foregoing, it is inferred that, the cry for alternative energy source has put charcoal Business as lucrative, although, there was alarm raised by environmentalist over massive logging of indigenous tree, but still charcoal business has played a major role in promoting entrepreneurial system in Nigeria. The data reveal that $94 \%$ have strongly believed that charcoal business has promoted diligent entrepreneurial, which confirmed that, The charcoal as source of cooking energy is cheaper than Kerosene, Gas and even firewood, as indicated by respondent opinion with $88 \%$. Therefore, the study can authoritatively conclude that Charcoal business has promoted entrepreneurial status in Nigeria. 


\section{References}

Alex Abutu , 8 December, (2011) (NEWS: U\$6M lost to illegal charcoal, wood export from Nigeria. Africa, Charcoal market, FAO,

Daily Trust 16 May ( 2011) published on Food and Agriculture, Business, Commodities, Nigeria, West Africa

Daily Trust 23rd January ( 2012) Enforce the charcoal export Ban ( published on Editorial Page31) Daily trust Nigeria, West Africa

Ismail AbdulAzeez (2012) Charcoal Export In Nigeria Top Secrets website: http//beyourownboss7.tripod.com

John P. Cunha, (2012) DO, FACOEP Medical Editor: Melissa Conrad Stöppler, MD, Chief Medical Editor

Karen Msiska (2012) 18 March 2012 10:19 When ending poverty outweighs sustaining environment, Africa, Charcoal, Charcoal market, Country, Energy Poverty, News

Kibiwott Koross,( 2012) published in the Nairobi Star and comes to us via AllAfrica news service Environmentalists Africa, Charcoal, Charcoal market, Kenya

Punch (2004) (The Punch, Thursday, April 8, 2004. page 22)

Steve Nix, (1997) About.com Guide (The History and Business of Making Lump Charcoal) About.com/The New York Times since 1997.

www.free Wikipedia, (2012) 